\title{
Medical Ethics and Competency To Be
} Executed

\author{
Rochelle Graff Salguero
}

\section{INTRODUCTION}

As a matter of statute ${ }^{1}$ or common law, ${ }^{2}$ and now as a matter of constitutional law, ${ }^{3}$ every death penalty jurisdiction forbids the execution of the incompetent condemned." This doctrine, called "competency to be executed," expresses a state policy of executing only those persons who understand that they are to be executed and why they are to be executed.5

1. Twenty-two states have enacted provisions proscribing the execution of the incompetent condemned. Ala. Code $\S 15-16-23$ (1982); ARIz. Rev. Stat. ANN. § 13-4021 (1982); ARK. Stat. Ann. § 43-2622 (1977); Cal. Penal Code § 3700-3704 (West 1982); Conn. Gen. Stat. § 54-101 (1985); Fla. Stat. ANN. § 922.07 (Harrison 1982); Ga. Code ANN. § 17-10-61 to -63 (1982); Ili. Rev. Stat. ch. 38, T 1005-2-3 (Smith-Hurd 1982); Kan. Stat. AnN. \$ 22-4006 (1981); MD. AnN. Code art. 27, § 75(c) (Supp. 1985); MAss. Gen. LAws ANN. ch. 279, § 62 (West Supp. 1986); Miss. Code ANN. $\$ 99-19-57$ (Supp. 1985); Mo. Rev. Stat. $\$ 552.060$ (Vernon Supp. 1985) Mont. Code AnN. § 46-19-201 to -202 (1985); Neb. Rev. Stat. § 29-2537 to -2538 (1979); Nev. ReV. Stat. § 176.425 to 455 (1986); N. M. Stat. ANN. § 31-14-4 to -14-7 (1978); N. Y. CoRRECT. LAw § 655-657 (Mckinney Supp. 1983); OHIo Rev. Code ANN. § 2949.28-30 (Page Supp. 1982) OkLA. Stat. ANN. tit. 22, § 1004-1058 (1958); Utah Code ANN. § 77-19-13 (1982); Wyo. STAT. § 7-13-901 to -903 (Supp. 1977).

Other statutes provide for transfer of all mentally incompetent prisoners to the state hospital. See Del. Code Ann. tit. 11, $\S 406$ (1982); Ind. Code Ann. $\$ 11-10-4-1$ to -4-5 (Burns 1981); N.C. GeN. Stat. § 15A-1001 (1983); S.C. Code ANN. § 44-23-210 (Law. Co-op. 1976); VA. Code § 19.2-177 (1983).

2. Four states have adopted, by case law, the common law rule prohibiting the execution of the presently incompetent. State v. Allen, 204 La. 513, 516, 15 So. 2d 870, 871 (1943); Commonwealth v. Moon, 383 Pa. 18, 22-23, 117 A.2d 96, 99-100 (1955); Jordan v. State, 124 Tenn. 81, 90-91, 135 S.W. 327, 329-30 (1911); State v. Davis, 6 Wash. 2d 696, 717, 108 P.2d 641, 651 (1940) (dictum). Idaho has a statute that provides for the adoption of the common law absent an explicit statutory provision. IDAHo CoDE $\S 73-116$ (1973). Therefore, the common law rule against executing the insane should apply.

3. Ford v. Wainwright, 106 S. Ct. 2595 (1986) (execution of insane violates Eighth Amendment proscription against cruel and unusual punishment).

4. The term "insane condemned" refers to inmates under sentence of death who become insane prior to execution. The state in this instance is concerned with competency only at the time of the execution; competency at the time of the crime or trial is assumed.

5. The rationale for the common law prohibition against executing an insane person is unclear. It is clear, however, that the doctrine has been a part of the English common law since the medieval period. Ford v. Wainwright, 752 F.2d 526, 530 (11th Cir. 1985) (Clark, J., dissenting), rev'd, $106 \mathrm{~S}$. C.. 2595 (1986).

Common law commentators have offered various explanations for the exemption. Blackstone, for example, suggested that the state of insanity itself served as sufficient punishment. $4 \mathrm{~W}$. BLACKSTONE, CommentaRies *395-96. Lord Coke stated that the deterrent effect of execution would not be served by execution of the insane, but instead would provide a "miserable spectacle . . . of extreame [sic] inhumanity and cruelty, and can be no example to others." CoKE, THIRD INSTITUTES 6 (6th ed. 1680). Sir John Hawles, Solicitor General in the reign of King William III, argued that executing insane criminals was inconsistent with principles of Christian charity because it deprived a man of his 
To effect this policy, the state requires the aid of the medical profession both to evaluate the condemned when issues of competency arise, and to treat the incompetent condemned for the purpose of restoring them to competency.

The physician is bound by a fundamental ethical principle to do no harm and to preserve life. ${ }^{b}$ Moreover, the physician is under an ethical duty to heal the sick and prevent suffering. ${ }^{7}$ In competency to be executed proceedings, the interest of the state in executing the condemned forces these two principles of medical ethics into conflict.

Procedures that require physician participation but violate medical ethics assume that the state interest in executing the condemned overrides concern for the ethical integrity of the medical profession. The physician cannot make an ethical choice. To comply with the interests of the state by providing treatment, the physician must violate a fundamental ethical prohibition, for without her treatment of the condemned, no execution would take place. Yet by refusing to treat the patient and thereby avoiding participation in the execution, the physician must forego her countervailing ethical duty to heal the sick and prevent suffering. The physician's dilemma is complicated when she is employed by the state and is therefore subject to sanctions ${ }^{8}$ for failure to comply with the treatment directive.

life before he could make his peace with God. Hawles, Remarks on the Tryal of Charles Bateman, in 11 State Trials *474, *477 (T. Howell ed. 1816). A final rationale rooted in the common law is that an incompetent inmate is unable to assist his attorney in pursuing viable legal issues that may still be present in his case. See 4 W. Blackstone, Commentaries at *395-96 ("the law knows not but he might have offered some reason, if in his senses, to have stayed these respective proceedings"). See also 1 Hale, The History of the Pleas of the Crown 34-35 (1736) ("defendant might allege somewhat in stay of judgment or execution").

A modern understanding of the exemption is based on a theory of retribution. In one view, retribution is satisfied when a wrong is offset by a punitive act of the same quality; killing an insane person does not have the same moral value or quality as killing a sane one. See Note, Insanity of the Condemned, 88 YALE L.J. 533, 536 (1979) (executing an insane prisoner would not satisfy retribution because society wishes to take a life of equal value to the one taken).

Another expression of this rationale is that the prisoner is required to perceive the "expression of society's moral outrage." Gregg v. Georgia, 428 U.S. 153, 183 (1976) (plurality opinion) (citations omitted). This goal is frustrated when the inmate is incompetent to comprehend the relationship between his conduct and the execution. See, e.g., Comment, Execution of Insane Persons, 23 So. CAL. L. REv. 246, 256 (1950) ("[I]f punishment . . . is an act of vengeance, then the prisoner's ability to appreciate his impending fate would seem to be the standard."); Note, Incompetency to Stand Trial, 81 HARv. L. REv. 454, 458-59 (1967) (retribution frustrated when one against whom punishment is inflicted cannot comprehend its significance). Indeed, according to one line of argument, retribution does not simply extend to comprehension of punishment, but also requires an element of mental suffering on the part of the condemned. See Radelet \& Barnard, Ethics and the Psychiatric Determination of Competency To Be Executed, 14 Bull. AM. ACAD. Psychiatry \& L. 37, 39-40 (1986).

6. See infra note 36 and accompanying text (discussing Hippocratic Oath).

7. For example, the code of ethics promulgated at the founding meeting of the American Medical Association pledged physicians to: "minister to the sick with due impressions of the importance of their office; reflecting that the ease, the health, and the lives of those committed to their charge, depend on their skill, attention and fidelity." R. VEATCH, A THEORY OF MEDical ETHICS 25 (1981) (quoting American Medical Association, Code of Ethics (1848)).

8. The state may exercise discretion over the employment, promotions, assignments, and salary of 
Part II of this Note will consider the extent to which Ford $v$. Wainwright ${ }^{9}$ and competency to be executed statutes require medical participation in the evaluation and treatment of the insane condemned. Part III examines medical ethics with respect to the role of healer, and the duty to do no harm and to take no life, and asserts that these two ethical strands clash when the physician is called upon to treat pursuant to competency to be executed statutes. Part IV analyzes the state interests in using the medical profession to implement these statutes. Part V examines possible resolutions to the ethical dilemma created by the state.

\section{The Necessity of Medical Involvement}

Although the rationale for the holding in Ford, ${ }^{10}$ as well as the states' competency to be executed statutes, all emerged from the same common law prohibition against executing the insane, the procedures chosen by the various states to implement the prohibition vary. The Ford decision invalidated Florida's statute on the grounds of inadequate procedural due process, ${ }^{11}$ but left unquestioned the necessity of psychiatric involvement. An examination of the Florida statute, the Ford Court's analysis of the statute, and the implications of this analysis for all state competency to be executed procedures, demonstrate that medical involvement is required to allow the state to execute the insane condemned.

\section{A. The Florida Statute}

Florida relies heavily on psychiatric testimony to determine competency. ${ }^{12}$ When the governor is informed that a condemned prisoner may be insane, he must stay the execution pending evaluation by an appointed commission of three psychiatrists. ${ }^{13}$ These psychiatrists must determine

the physician.

9. 106 S. Ct. 2595 (1986).

10. Id. at 2600 (Eighth Amendment "embraces, at a minimum, those modes or acts of punishment that had been considered cruel and unusual at the time that the Bill of Rights was adopted").

11. Id. at 2604 ("[T]his most cursory form of procedural review fails to achieve even the minimal degree of reliability required for the protection of any constitutional interest . . . .") (Marshall, J., plurality opinion). Justices Powell, $O^{\prime}$ Connor, and White also found the Florida procedures deficient. Id. at 2609-10 (opinion of Powell, J.); id. at 2613 (opinion of O'Connor, J., White, J., concurring).

12. Fla. Stat. ANN. $\S 922.07$ (Harrison 1982). Other statutes require only that a physician or physicians be used. See, e.g., MD. ANN. CoDE art. 27, \& 75 (Cum. Supp. 1985) (governor determines competency based on medical exams); Miss. CoDE ANN. § 99-19-57 (1972) (six physicians if possible). A small minority of states do not directly require medical involvement at this stage. See, e.g., ILL. REV. STAT. ch. 38, I 1005-2-3 (1982) (court decides at hearing if condemned prisoner has proven incompetency). However, because "[a] psychiatrist comes into the courtroom wearing a mantle of expertise that inevitably enhances the credibility, and therefore the impact, of the testimony" a psychiatrist is the logical choice for an expert witness in such a hearing. Amicus Curiae Brief for the American Psychiatric Association at 16, Barefoot v. Estelle, 463 U.S. 880 (1983) [hereinafter Barefoot Amicus Brief].

13. Fl.A. Stat. ANN. $\S 922.07(1)$ (Harrison 1982). 
whether the prisoner "understands the nature and effect of the death penalty and why it is to be imposed upon him."14 The governor, acting upon this information, may then decide that the person has the requisite understanding and sign an order for execution. ${ }^{15}$ Alternatively, he may decide that the condemned prisoner does not have the requisite understanding and commit him to the State Hospital for the Insane. ${ }^{16}$ At some time subsequent to commitment, when the prisoner appears to have regained competence, the governor appoints another commission of psychiatrists to determine competency. ${ }^{17}$ If the prisoner is found competent, the governor signs a warrant directing execution.

\section{B. The Ford Case}

These procedures were challenged by counsel for Alvin Ford, an inmate on Florida's death row, ${ }^{18}$ who contended that the Eighth Amendment prohibited the execution of the insane and guaranteed Ford greater procedural due process protection than that accorded by the statute. Five members of the Court held that the execution of the insane was proscribed by the Eighth Amendment. ${ }^{19}$ In addition, two members of the Court, while not subscribing to the constitutional analysis, agreed with the majority that the Florida procedures were inadequate. ${ }^{20}$

14. Id.

15. Id. at $\S 922.07(2)$.

16. Id. at $\S 922.07(3)$. Most statutes require treatment in a state medical facility. See, e.g., ARIz. Rev. Stat. ANN. § 13.4021-4024 (1978) (state hospital); Mass. Gen. Laws ANN. ch. 279, §62 (West Supp. 1985) (hospital at Massachusetts Correctional Institute, Bridgewater). A small minority do not specify a medical facility. See, e.g., Nev. REv. STAT. \$ 176.455 (1986) (confined in safe place until reason restored).

17. Fla. STAT. ANN. § 922.07(4) (Harrison 1982).

18. Ford was convicted of murder in 1974 and sentenced to death. His sanity during the commission of the offense, at trial, or at sentencing was not an issue. He began to manifest bizarre changes in his behavior in late 1981. See Ford, $106 \mathrm{~S}$. Ct. at 2598-99 (describing Ford's delusions). Ford's counsel subsequently engaged two psychiatrists to evaluate him. After both concluded that Ford suffered from paranoid schizophrenia, see Amicus Curiae Brief for the American Psychiatric Association (APA) at 2-3, Ford v. Wainwright, 106 S. Ct. 2595 (1986). Ford's counsel invoked the review procedures of Fla. StAT. ANN. § 922.07.

19. Justice Marshall wrote the opinion of the Court, holding that "whether [the prohibition's] aim be to protect the condemned from fear and pain without comfort of understanding, or to protect the dignity of society itself from the barbarity of exacting mindless vengeance, the restriction finds enforcement in the Eighth Amendment." 106 S. Ct. at 2602 . Justice Marshall also wrote an opinion, joined by Justices Brennan, Blackmun, and Stevens, holding that the Florida procedures were inadequate and that Ford was entitled to an evidentiary hearing in the United States District Court, de novo, on the question of his competency to be executed. Id. at 2606.

20. Justice O'Connor wrote an opinion, in which Justice White joined, agreeing that the hearing afforded by the Florida statute was not consistent with due process requirements. However, Justice O'Connor found that the statute created only a protected liberty interest, and did not rise to the level of a constitutionally protected right. Id. at 2611 (O'Connor, J., concurring in part and dissenting in part). Because the hearing was a state created entitlement, due process imposed "few requirements" and gave "broad latitude" to the state. Id. at 2612. Justice O'Connor concluded, nonetheless, that the inmate was entitled to an opportunity to be heard, which the Florida statute denied. Id. 
The Court did not question the propriety of medical involvement in the procedures. Rather, a majority recognized the inmate's interest in presenting medical evidence to dispute or support the state's findings on the issue of sanity, highlighting "the value to be derived from a factfinder's consideration of differing psychiatric opinions when resolving contested issues of mental state."21 Thus, psychiatric participation remains of paramount importance at the evaluation phase of the process.

Further, in all instances state statutes provide for execution following restoration of competency by physicians. ${ }^{22}$ The Ford Court neither questioned this provision, ${ }^{23}$ nor specified any particular mental state that would result in a finding of incompetence, ${ }^{24}$ leaving intact state definitions. Inmates who meet the definition of incompetence in states such as Florida often suffer from thought and affective disorders; ${ }^{25}$ because these disorders are properly treated by anti-psychotic medication, ${ }^{26}$ physicians must be involved to restore the inmates to competence.

\section{Increasing Medical Involvement}

The wretched living conditions, isolation, and unremitting terror of contemplating one's execution promote the deterioration of mental functioning in vulnerable individuals that is likely to lead to a legal determination of incompetence. Justice Frankfurter observed: "In the history of murder, the onset of insanity while awaiting execution of a death sentence is not a rare phenomenon."27

21. Id. at 2604 (Marshall, J., plurality opinion) (noting with approval Court's holding in Ake v. Oklahoma, 105 S. Ct. 1087 (1985)). Justice Powell also criticized the Florida procedures as inviting "arbitrariness and error by preventing the affected parties from offering contrary medical evidence." Id. at 2610 (Powell, J., concurring in part and concurring in judgment).

22. See, e.g., Mo. ANN. STAT. $\$ 552.060$ (Vernon Supp. 1986) (after prisoner is certified sane, governor will fix new date for execution). Only Montana suggests any possibility of discretion. "If -. . so much time has elapsed since the commitment of the defendant that it would be unjust to proceed with execution of the sentence, the court may suspend the execution of the sentence." MoNT. Code ANN. \& 46-19-202 (1985).

23. "[If] petitioner is cured of his disease, the State is free to execute him." $106 \mathrm{~S}$. Ct. at $2610 \mathrm{n} .5$ (Powell, J., concurring in part and concurring in judgment).

24. Justice Powell asserted that the standard must forbid "the execution only of those who are unaware of the punishment they are about to suffer and why they are to suffer it." Id. at 2609.

25. For example, Gary Alvord, the only Florida inmate in recent history to be declared incompetent to be executed, was diagnosed as a paranoid schizophrenic. Krasnow, Condemned by Reason of Sanity, Times Union (Jacksonville, Fla.), Aug. 25, 1985, at A-1, col. 6.

26. For example, phenothiazines are used to treat such symptoms as hallucinations, psychotic thought processes, bizarre responses, and paranoia. Davis, Antipsychotic Drugs, in The CompreHeNSIVE TEXTBOoK OF PsychistRY 2257-59 (1980). Lithium is the most effective treatment available for manic-depressive disorders, acting on the "grandiosity . . . paranoid rages . . . and religious delusions" typical of this disorder. Fieve, Lithium Therapy, in The Comprehensive TeXTBOOK of PSyChIATRY 2348 (1980). Federal prescription laws require that only licensed physicians may prescribe medication for human consumption.

27. Solesbee v. Balkcom, 339 U.S. 9, 14 (1950) (Frankfurter, J., dissenting). The majority in Solesbee sustained the constitutionality of GA. CODE $\S 27-2602$, which provided that the governor, 
A death sentence and the grim quality of life on death row frequently have been linked to stress and psychiatric illness. Several studies note the psychological deterioration of condemned inmates. ${ }^{28}$ These studies relate the mental illness not only to the conditions on death row, but also to the unique stress of anticipating one's death at a known time and in a predesignated manner. ${ }^{28}$ Similarly, detailed profiles of individual inmates document overwhelming stress and dehumanization..$^{30}$

The situation caused by this environment, which fosters mental deterioration, is aggravated by the current judicial tilt towards capital punishment. The population on death row, estimated at 1,500 inmates, continues to grow. ${ }^{31}$ Many inmates have been residents of death row for substantial periods of time. ${ }^{32}$ The pace and complexity of the present death penalty process guarantees a long wait between sentence and execution. ${ }^{33}$ Clearly, post-sentencing incompetence will become more common. Therefore, doctors can anticipate that the state will require their services more fre-

assisted by medical reports, could determine sanity following conviction of a capital offense, even though the decision could not be appealed and there was no adversary hearing.

28. See, e.g., Bluestone \& McGahee, Reaction to Extreme Stress: Impending Death by Execution, 119 AM. J. Psychiatry 393 (1962). In their study of death row inmates at Sing Sing, the authors detailed various symptoms and psychological defense mechanisms displayed by the inmates. For example, the authors noted that one prisoner had become "progressively more suspicious and grandiose during his death house stay." Id. at 394. See also Gallemore \& Panton, Inmate Responses to Lengthy Death Row Confinement, 129 AM. J. Psychiatry 167 (1972) (detailing psychiatric deterioration of individuals confined to death row in North Carolina for over two years). A study of death row in Alabama confirmed findings of psychological despair and thoughts of suicide among death row inmates, and found that normal psychological defense mechanisms do not suffice to manage the stress. R. Johnson, Condemned To Die: Under Sentence of Death 111 (1981).

29. Bluestone \& McGahee, supra note 28, at 393; Gallemore \& Panton, supra note 28, at 167.

30. In C. DAvis, Waiting For IT (1980), a study of condemned inmate Troy Gregg on death row in Georgia, the author notes that in "dealing with the threat of their imminent extinction . . . [t]hose with natural balance and strength of mind survive more or less intact until they are killed. The rest fail visibly from month to month and are destroyed in effect before the state can do its work." Id. at 157. See also S. GetTinger, Sentenced To Die 93 (1979) (collection of eight case histories of murderers on death row, concluding that central truth of life on death row is "the intense psychological stress"). Gettinger quotes a study by Dr. Louis J. West, a psychiatrist who described death row as a "grisly laboratory . . . the ultimate experimental stress, in which the condemned prisoner's personality is incredibly brutalized." Id. at 94. See also B. JACkson \& D. Christian, Death Row 11 (1980) (life on death row in Texas depicted as "a world of enormous sensory overload and sensory deprivation").

31. 20 Psychiatric News, Dec. 6, 1985, at 14, col. 3. At the end of 1984, the Department of Justice reported that 1,405 people were on death row in the United States. See Bureau of Just. Statistics Bull., Aug. 1985, at 5.

32. In 1984, the median time on death row was 33 months. Bureau of Just. Statistics Bull., Aug. 1985 , at 1. By comparison, in 1983 the median time on death row was only 28 months, although almost 3 out of 10 inmates had been on death row at least 4 years, including 143 persons who had been waiting to be executed for 6 or more years. Bureau of Just. Statistics Bull., July 1984, at 3-4.

33. Richard Burr, the attorney for condemned inmate Alvin Ford, remarked that "competence at the time of execution is an issue that the modern criminal justice system has made worse. People are in virtual solitary confinement on death row for many years as the lengthy but necessary review of their sentence unfolds." 13 Clinical Psychiatry News, Apr. 1985, at 25, col. 4. 
quently to provide evaluations and treatment pursuant to competency to be executed statutes.

\section{Medical Ethics and Competency To Be Executed}

\section{A. The Oath and Ethical Codes}

If the psychiatrist in a competency to be executed proceeding were functioning solely as an autonomous person, the propriety of participation would be based on individual morality and ethics. However, the psychiatrist's involvement is premised on her status as a licensed member of the profession. By virtue of her membership, the psychiatrist must observe explicit ethical principles of the profession. ${ }^{34}$ Arguably, a fully competent physician must be an ethical physician. ${ }^{35}$

The Hippocratic Oath is a primary source of medical ethics which defines the role of healer, requiring respect for the patient and imposing a duty to do no harm and take no life. ${ }^{36}$ It has "come down through history

34. In medical practice, ethics are not merely good manners or etiquette. One commentator describes the relationship between ethics and medical practice:

Both medicine and law are properly called "learned and ethical professions". . . . The term "profession" or "ethical profession" is used because the qualified physician or attorney must in fact profess a specific set of normative or ethical committments. Thus, to be "learned" is to be the master of special knowledge and technique; to be of the "profession" is to be committed to using that knowledge and technique in the service of certain fundamental values. ... In medicine, the ultimate such value is life-or, more fully, the protection, preservation, and (when possible) improvement of life and health. To be indifferent to health or sickness, to life or death, is to have abandoned medicine as an ethical profession.

Derr, Why Food and Fluids Can Never Be Denied, 16 Hastings Center Rep. 28, 29 (Feb. 1986).

The decision to impose sanctions is not the only indication of an ethical breach. However, for APA members, violation of these ethical principles will result in the imposition of various sanctions, ranging from reprimand to expulsion from the organization. AMERICAN Psychiatric Association, The Principles of Medical Ethics: Wrth Annotations Especially Applicable to Psychiatry 10 (1985) [hereinafter Principles]. Under certain circumstances, information regarding the ethical breach will be disclosed to "any medical licensing authority, medical society, hospital, clinic, or other institutions or persons where such disclosure is deemed appropriate to protect the public." Id. at 15 (quoting american Psychiatric association Bylaws ch. 10, $\$ \S 1,2$ ).

35. The section of the PRINCIPLES concerning provision of "competent medical service" is defined by the APA to refer to the psychiatrist's ethics and professional responsibility. PRINCIPLes, supra note 34 , at $\S 1(1)$ (emphasis added). Further, "[t]he medical and nursing professions are consecrated to preserving life. That is their professional creed. To them, a failure to use a simple, established procedure in the circumstances . . . would be malpractice, however the law may characterize that failure." John F. Kennedy Memorial Hosp. v. Heston, 58 N.J. 576, 582, 279 A.2d 670, 673 (1971) (blood transfusion justified by interest of hospital and its staff, as well as state's interest in life).

The proposition that ethical conduct is a component of professional competence has also been acknowledged in the legal profession: "[A]biding by the codes of professional conduct applicable to one's profession is an attribute of professional competence as well as evidence of trustworthiness." Leleiko, Professional Responsibility and Public Policy Formation, 49 ALB. L. REv., 403, 412 (1985) (referring to lawyers who function within the area of policymaking).

36. The Hippocratic Oath probably dates from the fourth century B.C. R. VEATCH, supra note 7, at 19-20 (citing L. Edelstein, Ancient Medicine: Selected Papers of Ludwig Edelstein 55 (1967)). Versions of the Oath may be found in such publications as BrIt. MED. Ass'N, THE Handbook of Medical Ethics 63-64 (1981); Psychiatric Ethics 343-44 app. (S. Bloch \& P. Chodoff eds. 1981); W. Osler, The Evolution of Modern Medicine 63-64 (1921). The Oath 
as a living statement of ideals to be cherished by the physician,"37 and is "the central document, the single most often-cited summary of the physician's own understanding of what is morally required to be a good medical doctor." ${ }^{38}$ The significance of the Oath is so considerable that medical students are taught: "From the point of view of the patient-doctor relationship the most important rule in practice is the classical non nocere [do no harm] demand, already formulated by Hippocrates."39

Those outside the medical profession also view the Oath as central to the practice of medicine. One commentator remarked that the Oath's "spirit influences much of health care and it is frequently invoked as normative by the layman." 40 The significant point is that both physicians and the society in which they work view the Oath as a distillation of medical ethics, as well as a legitimate standard of evaluation for medical performance.

In addition to the Oath, physicians have promulgated various codes of ethics. The World Medical Association has written a modern restatement of the Oath, namely, the Declaration of Geneva. ${ }^{41}$ It emphasizes the role of healer: "[T]he health of my patient will be my first consideration."42 Similarly, the Declaration of Hawaii, adopted by the World Psychiatric Association, states that "[t]he aim of psychiatry is to promote health and

states: "I will follow that system of regimen which, according to my ability and judgment, I consider for the benefit of my patients, and abstain from whatever is deleterious and mischievous. I will give no deadly medicine to anyone if asked. Into whatsoever houses I enter, I will go into them for the benefit of the sick." Oster, id. at 64 . A somewhat different translation reads: "I will apply . . . measures for the benefit of the sick according to my ability and judgement; I will keep them from harm and injustice." Psychiatric Ethics, supra, at 343. A Christian version is found in Chambers, Ethics or Medical Ethics, 24 MED. SCI. L. 17, 18 (1984).

37. Preface, Current Opinions of the Judicial Council of the AMA vii (1982). The Judicial Council publishes Rules of the Judicial Council to inform its membership of medical ethics.

38. R. VEATCH, supra note 7, at 18-19. Veatch asserts that the code is binding only on those parties who have agreed to it; that is, the members of the medical profession. As such, he feels that the Oath is of little relevance to the resolution of questions of medical ethics when the interests of society, which is not a party to the Oath, are involved. The public regularly demonstrates a different interpretation, see supra note 34 and accompanying text, as does the judiciary, which refers to the Oath when considering issues that involve the relationship between the medical profession and patients. See, e.g., Hammonds v. Aetna Casualty \& Surety Co., 243 F. Supp. 793, 801 (N.D. Ohio 1965) ("Almost every member of the public is aware of the promise of discretion contained in the Hippocratic Oath, and every patient has a right to rely upon the warranty of silence."); Shaw v. Glickman, $45 \mathrm{Md}$. App. $718,725,415$ A.2d 625, 630 (1980) (doctor's obligations to patients defined by Hippocratic Oath).

39. V. TähkÄ, The Patient-Doctor Relationship 38 (1984). Because this source is a textbook, it may be understood to distill the essence of what one generation of doctors desires to pass on to the next.

40. Chambers, Ethics or Medical Ethics, 24 MED. ScI. L. 17, 18 (1984) (citing V. NuTton, Dictionary of Medical Ethics (Dunstan ed. 1981)); see also supra notes 34, 36 (describing public expectation that physicians will abide by Oath).

41. Psychiatric Ethics, supra note 36, at 344 (Declaration, adopted in 1948 and amended in 1968, included).

42. Id. 
personal autonomy and growth. . . Every patient must be offered the best therapy available."13

These codes reflect the tradition of doing no harm to the patient. As applied to executions, the House of Delegates of the American Medical Association (AMA) has expressed this precept in its statement that a "physician, as a member of a profession dedicated to preserving life when there is hope of doing so, should not be a participant in a legally authorized execution."14 Also, psychiatrists who are members of the American Psychiatric Association (APA) ${ }^{\mathbf{4 5}}$ are bound by the AMA ethical guidelines as annotated for psychiatrists, which state that while it is appropriate for psychiatrists to serve as consultants to the judiciary, "[a] psychiatrist should not be a participant in a legally authorized execution."47

The Hippocratic Oath and the codes of ethics suggest that the duty to treat and comfort the sick is integral to the role of being a physician. Consequently, the physician who encounters a condemned patient who is mentally ill will wish to treat the individual, ${ }^{48}$ yet also to do no harm to the patient by restoring the requisite competency for execution.

\section{B. The Ethical Conflict}

Medical ethics may be implicated whenever psychiatric participation in capital proceedings is required. Psychiatrists have long been involved in assessing competency to stand trial, ${ }^{48}$ predicting future dangerousness, ${ }^{80}$

\footnotetext{
43. Id. at 350 (adopted in Honolulu in 1977).
}

44. Capital Punishment, Proc. House Delegntes AMA 85, 86 (1980). Controversy within the profession about this provision reflects uncertainty as to the meaning of the term "participate." The National Medical Association Section on Psychiatry and Behavioral Sciences, an organization of minority physicians, holds that doctors should treat the condemned mentally ill, but "under no circumstances directly or indirectly assist in an execution of a 'death row' inmate." National Medical Association Section on Psychiatry and the Behavioral Sciences, Position Statement on the Role of the Psychiatrist in Evaluating and Treating Death Row Inmates, at 5 [hereinafter NMA Position Paper]. In contrast, the Florida Mental Health Association found the involvement sufficiently unethical that it urged all mental health professionals to boycott determinations of competence to be executed. See Proposed Public Policy Position Regarding Mental Capacity To Be Executed of the Florida Mental Health Association (1984) [hereinafter FMHA Policy Statement].

45. Approximately 32,000 of the 40,000 psychiatrists practicing in the United States are members of APA. Motion for Leave To File Brief Amicus Curiae for the APA, Ford v. Wainwright, 106 S. Ct. 2595 (1986).

46. Principles, supra note 34 , at $\S 7(1)$.

47. Id. at $\S 1(4)$. The proscription is binding on members of the APA through ch. $8, \S 1$ of the APA bylaws. See Principles, supra note 34 , at $\S 7(1)$.

48. A physician is, of course, not bound to treat every patient she encounters. However, this discretion is usually limited to non-emergency situations in which another physician is available to meet this person's needs. See Principles, supra note 34, at $\$ 6$ ("A physician shall . . . except in emergencies, be free to choose whom to serve.").

49. For a modern statute requiring psychiatric involvement in these proceedings, see the Insanity Defense Reform Act of 1984,18 U.S.C. $\S 4241$ (1983) (psychiatrist required for assisting in determination of incompetency).

50. This role is prescribed in capital sentencing by statutes that require the jury to determine whether there is a probability that the defendant would commit criminal acts of violence that would 
and determining competency to waive appeal. ${ }^{51}$ Medical ethics in these proceedings are often examined in the context of the forensic psychiatrist, ${ }^{52}$ who may owe "dual allegiances" to the state and the profession, thus creating considerable concern that the medical well-being of a patient is subordinate to duties to the employer. ${ }^{53}$ Any psychiatric participation in capital proceedings arguably raises the ethical duty of the physician not to take life. However, total physician abstention from these proceedings may adversely affect the exercise of individual rights associated with the criminal justice process. For example, the constitutional right to a fair trial requires that a person be competent to stand trial. ${ }^{54}$ Were psychiatrists to refuse to make competency determinations at capital proceedings, a constitutional right of the defendant would be imperiled. Further, physician responsibility at this stage of the criminal process for an inmate's execution is quite attenuated. The accused still enjoys the presumption of innocence; he may plead guilty to avoid the death penalty; and even if the accused is convicted, the jury may choose not to impose a death sentence, or the judge may direct that the sentence not be imposed. In competency to waive appeal proceedings, the inmate may be making a conscious choice to forego potentially life-sparing action, analogous to the situation where a physician respects a competent patient's right to die. ${ }^{.5}$

The ethical question which this Note identifies, therefore, focuses on psychiatric involvement in competency to be executed proceedings. Some psychiatrists assert that the initial evaluation of an inmate for competency

constitute a continuing threat to society. See TEx. CODE ANN. art. 37.071 (Vernon 1981). The use of psychiatrists becomes both desirable and necessary from the point of view of the prosecution and the defense. Cf. Barefoot Amicus Brief, supra note 12 (criticizing the role of psychiatrists in these proceedings).

51. See, e.g., Rees v. Peyton, 384 U.S. 312 (1966) (per curiam) (judicial determination of inmate's mental competence to refuse assistance of counsel and terminate legal proceedings required); see also Gilmore v. Utah, 429 U.S. 1012, 1015-16 nn.4-5 (1976) (defendant made "knowing and intelligent waiver" of federal rights after death sentence imposed).

52. Forensic psychiatrists use psychiatric principles and techniques to enable courts to arrive at legal determinations.

53. In the traditional doctor-patient relationship, the physician obtains confidential information from the patient for therapeutic purposes. In contrast, the forensic psychiatrist routinely gathers information for non-therapeutic purposes for the benefit of third-party employers. For this reason, among others, the practice of forensic psychiatry has provoked considerable debate about appropriate medical ethics and roles. See, e.g., J. Robirscher, The Powers of Psychiatry (1980); Bazelon, The Law, the Psychiatrist, and the Patient, 5 MAN \& MED. 77, 81 (1980) ("The question of divided loyalties is of direct relevance when psychiatrists are called upon, as they are continually, to make important decisions in a legal setting."); Rappeport, Ethics and Forensic Psychiatry, in Psychiatric ETHICs 255 (forensic psychiatry still a relatively new science, hence ethics yet to fully develop). See generally T. Szasz, Psychiatric Justice (1965) (asserting that psychiatrists must never use their professional tools to assist the law).

54. Cf. Dusky v. United States, 362 U.S. 402 (1960) (per curiam).

55. See In re Quinlan, 70 N.J. 10, 355 A.2d 647, cert. denied, 429 U.S. 922 (1976). See generally Byrn, Compulsory Lifesaving Treatment for the Competent Adult, 44 FordHaM L. REv. 1 (1975) (analyzing right to die cases). 
implicates the taking of life and is thus prohibited. ${ }^{58}$ However, in performing an evaluation, the role of the physician as a healer is not necessarily implicated. "[T]o pretend that the usual doctor-patient role is in effect during a forensic examination is patently dishonest and unethical." withstanding the psychiatrist's proximity to the execution process, if she properly informs the inmate of the purpose of evaluation and the lack of confidentiality, her function is that of a court consultant, which is ethically permissible. ${ }^{58}$ Further, refusing to evaluate may lead to death, ${ }^{58}$ while a diagnosis of incompetency presents the life-affirming possibility of a stay of execution. The inmate is under a sentence of death, which the psychiatrist can either affirm, in which case nothing has changed, or delay through a finding of incompetency, preserving an inmate's life. ${ }^{60}$

However, the ethical implications change in the treatment phase of competency to be executed proceedings. This Note proposes that in the treatment phase, the moral culpability of the physician is so clear and direct that it is justifiable to draw a line and recognize the physician's ethical objections. An analogy can be made to the doctrine of causality in the criminal law with regard to homicide. This doctrine is expressed in the Model Penal Code $\S 2.03$ (1985), which states: "Conduct is the cause of a result when: (a) it is an antecedent but for which the result in question would not have occurred ...." or knowingly" causing the death of another human being. ${ }^{62}$ In turn, this intent requirement is satisfied when death was within the purpose or the contemplation of the actor.

The proximity of the psychiatrist's actions to execution is such that but for the physician's conduct, the inmate would not die. The inmate is under a stay of execution that expires upon the restoration of sanity. Thus, the act of treatment and restoration of sanity is the only condition precedent for the execution of the individual. This result is in the contemplation of the physician because the patient is explicitly referred to the

56. Dr. Paul Applebaum, chairman of the Judicial Council of the American Psychiatric Association's Commission on Judicial Action, asserted that "psychiatrists really as physicians, as healers, have no place anywhere near these determinations." Nightline: Catch 22: Curing Prisoners . . . To Die (ABC television broadcast, Mar. 6, 1986) [hereinafter Nightline] (statement of Dr. Paul Applebaum, appearing in his individual, not official, capacity).

57. Rappeport, supra note 53 , at 263.

58. See Principles, supra note 34, at § 4(6) ("Psychiatrists are often asked to examine individuals . . . to determine legal competence. The psychiatrist must fully describe the nature and purpose and lack of confidentiality of the examination to the examinee at the beginning of the examination."); Rappeport, supra note 53, at 262 ("It is imperative that the patient be informed clearly whose servant the interviewer is.").

59. Absent a finding of incompetency, the inmate will be executed.

60. See Radelet \& Barnard, supra note 5, at 49-50.

61. Model Penal Code $\S 2.03$ (1985).

62. Model. Penal. Code $\S \S 210.1,210.2$ (1985). 
physician for treatment pursuant to the statute. Thus, the physician knows that successful treatment renews the inmate's death warrant, and the causation is proximate. But for state exoneration of her action, similar to the privilege accorded soldiers in battle, the physician is taking life in violation of her ethics. This exemption may insulate the physician from legal liability, but in no way diminishes the ethical violation.

This procedure is particularly egregious for the physician because she cannot fulfill her ethical role of healer by treating the sick and preventing suffering. ${ }^{63}$ In a bizarre twist of the medical treatment situation, the express purpose of competency treatment is to guarantee that the patient will be killed. ${ }^{64}$ Each treatment strategy to heal the inmate is in fact another strategy to ensure his death. No intervening acts save the miniscule likelihood that, once sane, the inmate will articulate a heretofore unknown reason for a stay of execution, ${ }^{65}$ will prevent the execution that the physician has made possible.

The present ethical dilemma is, in part, a result of the modern psychiatrist's ability to treat successfully the mentally ill. Doctors have had effective drugs to control psychotic symptoms for only the past thirty years. ${ }^{68}$ Historically, treatment for psychosis was at best custodial, and at worst harmful; hence, an insane person rarely regained his sanity. ${ }^{67}$ The exemp-

63. Despite serious misgivings about the involvement of psychiatrists in incompetency to be executed proceedings, one medical group stated that it could "not advise psychiatrists to refuse to evaluate and treat patients who are unfit for execution as this would constitute a failure to perform a psychia. trist's duty, i.e. to provide evaluation and treatment to the mentally ill." NMA Position Paper, supra note 44 , at $2-3$.

64. On its face, the purpose of treatment is to cure the patient, and the consequence of the cure is to enable the state to execute. However, because the execution is in the contemplation of the psychiatrist when she commences treatment, the distinction is meaningless. See supra notes 61-62 and accompanying text (discussing Model Penal Code definition of culpability).

65. See Ford v. Wainwright, 752 F.2d at 528, rev'd, 106 S. Ct. 2595 (1986). Dr. Radelet noted that the only case he had found supporting the common law rationale was a case in which a man was sentenced to death, found incompetent, and confined to a mental hospital for thirty years. He was then found innocent of his crime. Nightline, supra note 56, at 4.

66. See S. Alexander \& F. Selesnick, The History of Psychiatry 287-91 (1966) (tracing the development of psychotropic drugs); Klerman \& Schechter, Ethical Aspects of Drug Treatment, in Psychiatric ETHics, supra note 36, at 117-18 (describing "modern revolution" created in mental health care through development and use of psychotropic drugs in late 1950's).

Chlorpromazine and other anti-psychotic drugs have been tested in hundreds of double-blind studies. In a typical study conducted by the National Institute of Mental Health, about $70 \%$ of the patients improved significantly with phenothiazine therapy, while one-tenth showed no improvement and none showed deterioration. In contrast, one-fourth of the placebo group showed moderate to marked improvement and almost half remained unchanged or became worse. Davis, Organic Therapies, in The Comprehensive Textbook of Psychiatry 2257-58 (1980).

67. Seventeenth-century Europeans, for example, tended to view mental illness as a manifestation of demonic possession and treated the disorder with the scourge, the rack, the stake and the gallows. A. Deutsch, The Mentally Ill in America 24-25 (1937). By the eighteenth century, treatment, when administered, often consisted of "emetics, purgatives, bloodletting and various so-called harmless tortures provided by special paraphernelia." F. ALEXANDER \& S. SELESNICK, supra note 66, at 114. The neglect and poor treatment attendant on such views of mental illness killed many patients. Id. at 116. Psychoanalysis was a significant therapy in the early twentieth century, but Freud himself con- 
tion thus effectively functioned as a reprieve. It is reasonable to assume that medical advances will continue to provide more effective means for treating the mentally ill. This trend, coupled with predictions of increasing numbers of incompetent condemned inmates on death row, makes the ethical conflict centered on treating the condemned a very serious problem for physicians and society.

\section{A Case Study in Florida}

A recent case in Florida demonstrates the intensity of the ethical dilemma. Pursuant to the statutory process ${ }^{68}$ Gary Eldon Alvord, convicted killer of three Tampa women, was examined by a panel of three psychiatrists and found incompetent to be executed. ${ }^{69}$ Alvord was subsequently committed to the Chattahoochee State Hospital for the purpose of being restored to competency so that he might be executed. ${ }^{70}$

Response to Alvord's presence at the hospital was immediate. The Florida Mental Health Association (FMHA) issued a proposal that attempted to address both the duty to alleviate suffering and the duty to avoid participation in an execution. The result was a statement with contradictory provisions. ${ }^{71}$ The Human Rights Advocacy Committee of the hospital raised questions pertaining to the participation of staff members in restoring competency, and endorsed the FMHA position. ${ }^{72}$ The committee recommended that before hospital staff be required to treat the incompetent

ceded that it was of small utility in the treatment of psychotic symptoms. A. Norton, ThE New Dimensions of Medicine 140-141 (1969).

Statistics on rates of cure with these old forms of treatment are sparse, and are generally viewed as unreliable because of distortions in the manner of compiling and reporting. One study cites a recovery figure of about $15 \%$ in 1937 , A. Deutsch, supra, at 148, and it is unlikely that the primitive treatments used prior to this time raised that figure substantially. See id. at 147-57 (criticizing earlier cmphasis on cure rates). In contrast, the literature of the late 1960's was already referring to "the ease and speed with which many psychotic illnesses can be treated today." A. NORTON, supra, at 144.

68. Fla. Stat. ANN. § 922,07 (Harrison 1982).

69. Two of the psychiatrists, Peter Ivory and Gilbert Ferris, were state employees working at the Chattahoochee State Hospital, while the third, Umesh Mhatre, was not a state employee. Miller \& Walker, Alvord 'Incompetent'; Sent to Chattahoochee, Tampa Tribune (Fla.), Nov. 27, 1984, at 1B, col. 3, 2B, col. 2 .

70. Alvord resides in the new Corrections Mental Health Institution on the hospital grounds, which is jointly operated by the state health agency and the state corrections department. Krasnow, supra note 25 , at $A-1$, col. 6 .

71. The Association opposed the "appointment of government psychiatrists to determine mental capacity to be executed, endorsed increasing the provision of mental health services to death row inmates, [and] opposed the involuntary treatment of those who are incompetent to be executed." FMHA Policy Statement, supra note 44.

72. Peter Ostreich, chairman of the committee, observed, "[m]ental-health treatment is supposed to be provided for the benefit of the patient . . . . This treatment is not going to be of any benefit to him." Leonard, Death Row Inmate's Treatment Sparks Controversy, Tallahassee Democrat (Fla.), Dec. 12, 1984, at A1, col. 1. 
condemned, the sentence be commuted to life imprisonment; ${ }^{73}$ staff treatment thus would not advance the patient toward execution. ${ }^{74}$

\section{The State Interest}

The state interest in utilizing physicians both for their professional skills and the humane appearance their presence brings to the proceedings is in tension with competing state values in protecting the integrity of the medical profession-and the public's perception of the medical role-from identification with the spectre of the executioner.

\section{A. Arguments Favoring Use of Physicians}

When the state makes the somber and serious decisions to enact a death penalty statute and to sentence a particular person to death, the state clearly has an interest in executing that person. ${ }^{75}$ Nevertheless, the state is prohibited from executing the insane condemned, ${ }^{76}$ and hence may never exercise the power to execute if the inmate is permanently insane. Circumstances, therefore, do exist that override the state interest in execution. Justice Frankfurter wrote that, "[t]he risk of an undue delay is hardly comparable to the grim risk of the barbarous execution of an insane man." $" 77$

Clearly, the state retains an interest in ensuring that competent prisoners do not frustrate, with false pretensions of incompetency, the state's ability to carry out an execution. The Court has expressed concern that "it would be wholly at the will of a convict to suffer any punishment whatever, for the necessity of his doing so would depend solely upon his fecundity in making suggestion after suggestion of insanity, to be followed by trial upon trial."

73. Id. at A1, col. 2.

74. Alvord was treated at the State Hospital by a volunteer staff. Krasnow, supra note 25, at A13, col. 1. Staff at the Corrections Mental Health Institution where Ford was transferred were given the choice of "opting out" of participation in treatment of Alvord. Id. at col. 2. Dr. Loren Roth, director of the APA Council on Law and Psychiatry stated: "We certainly recognize the troublesome and anomalous position the staff at the hospital is being put in." Id. at col. 1. Dr. Roth also stated that there is no easy answer to the dilemma of whether to treat death row inmates for psychiatric disorders. "Certainly medicine is devoted to the relief of suffering wherever that may be . . . . These people are sick and they are suffering." Id.

75. This is true only if one accepts that the death penalty is a legitimate exercise of state authority; the Supreme Court has found it to be so. See Gregg v. Georgia, 428 U.S. 153 (1976).

76. Ford v. Wainwright, 106 S. Ct. 2595 (1986).

77. Solesbee v. Balkcom, 339 U.S. 9, 25 (Frankfurter, J., dissenting).

78. Nobles v. Georgia, 168 U.S. 398, 405-406 (1897) (holding due process clause does not guarantee condemned prisoner right to jury trial on issue of present competency). Among the solutions proposed to address this possibility are relying on a "probable cause" requirement for granting a stay of execution, see Note, The Eighth Amendment and the Execution of the Presently Incompetent, 32 STAN. L. REv. 765, 803 (1980), and restricting condemned inmates to one full hearing on an insanity claim, with future proceedings on subsequent claims expedited. See Note, Insanity of the Condemned, 
physicians evaluate those condemned inmates whose competency is in question. Employing a physician to screen out such frivolous claims, however, does not bring the ethical conflict to the fore, because it only implicates the physician's role as evaluator and consultant to the court. ${ }^{79}$

Another justification for the use of physicians is to implement the statute in a manner that is fair, scientific, and reliable. ${ }^{80}$ The physician's expertise increases the probability that treatment decisions will be accurate and effective, enabling the state to proceed with the execution. Also, the profession's integrity is superimposed on the proceedings, sanitizing the execution and lending an aura of propriety and humaneness. But treatment in this context is in the best interest of the state, not the best interest of the patient, who will die if treatment succeeds. ${ }^{81}$ The state is asking the physician to treat an unwilling individual ${ }^{82}$ in order to change him to meet the will of society, which is especially repugnant to medical ethics. ${ }^{83}$

supra note 5, at 563. The state's interest in preventing inappropriate delay of execution is complicated by the fact that the inquiry addresses competency at the moment of execution. Obviously, competency cannot be determined at the moment of execution; consequently, the prisoner is able to raise repeated claims up to the actual moment of execution. See Hazard \& Louisell, Death, the State, and the Insane: Stay of Execution, 9 UCLA L. REv. 381, 400 (1962).

79. See supra note 57 and accompanying text.

80. Because of their specialized knowledge and the vulnerability of their patients, members of the medical profession have traditionally been regarded by the public as particularly trustworthy and responsible. See, e.g., Hammonds, 243 F. Supp. at 797 (public has right to rely on medical code of ethics); MacDonald v. Clinger, 446 N.Y.S.2d 801, 805 (App. Div. 1982) (relationship of parties one of "trust and confidence" which is "essential to the doctor-patient relationship"). The psychiatrist provides an aura of certainty, wearing a mantle of expertise that lends credibility to the process. See Barefoot Amicus Brief, supra note 12, at 9, 16.

Critics of the use of physicians in capital proceedings attribute different motives to the state. One critic of physician participation in lethal injections notes that the true appeal of using physicians is not that the prisoner feels less pain, but that a medical veneer is superimposed on the act. The veneer creates a "false image about an act which is quite final and quite dehumanizing," 'because the injection is given by health professionals, who are considered to have the "highest developed quality of love for humanity." "Malone, Death Row and the Medical Model, 19 The Hastings Center Rep. 5 (Oct. 1979) (quoting Bristow, Forum on Medicine (June 1979)). Another critic suggests that the physician is used to replace the "monster-like figure of the executioner" with the "more benign, if no less deadly, appearance of the medical professional." Finks, Lethal Injection: An Uneasy Alliance of Law and Medicine, 4 J. LEGAL MED. 383, 383 (1983). One author asserts that Florida psychiatrists are used as pawns, moved by the political fortunes of the Governor. See The Politics of Death, THE NATION 636, 637 (Dec. 15, 1984). The author speculates that the finding of incompetency for Alvord reflects the national political ambitions of the Governor, and his concern about the public perception of him as a "crackpot zealot" who gets "writer's cramp from signing death warrants." Id. at 637.

81. This Note assumes that it is in the best interest of the patient to both live and be cured. However, given the contingencies arranged by the state, these outcomes are mutually exclusive. Therefore, the physician cannot act in the best interests of her patient.

82. Arguably, some inmates may want to die. The implication of medical involvement in "suicide" or "right to die" cases is beyond the scope of this Note. Unlike these cases, which set medical ethics against patient autonomy, this Note considers the situation in which the ethics of the physician coincide with the independent will of the inmate to live.

83. See Merskey, Ethical Aspects of the Physical Manipulation of the Brain, in Psychiatric ETHIcs, supra note 36 , at 131 . Thus, requiring physicians to participate in the treatment of the insane condemned in violation of their ethics "would tend to reduce the medical professional to a skilled tradesman without ultimate normative commitments." Derr, supra note 34 , at 30 (arguing that denial of food or fluids to any patient violates medical ethics). When the state permits or encourages 
A final argument for participation highlights the physician's putative obligation to perform duties for the state which the state deems legitimate and necessary. ${ }^{84}$ The physician's obligation becomes a duty if the physician maintains an employment relationship with the state. ${ }^{85}$ This "good citizen" model of physician compliance with the mandate of the state proves too much. One can be a good citizen and conscientiously question the objectives of the state; ${ }^{86}$ indeed, one can be a good citizen and refuse to obey a directive of the state. ${ }^{87}$ The issue is whether the physician's responsibility to society is best discharged by observing professional standards or by complying with the dictates of law and custom. ${ }^{88}$ Medical experiments of physicians in Nazi Germany provide a chilling example of the risk society takes when it encourages doctors to subvert their ethics in the service of the state.

this "degradation of the medical profession," id., the results can be tragic for society. The most extreme example is the Nazis, who used physicians as an integral part of their euthanasia program for thousands of mentally disabled and handicapped patients. Chodoff, The Responsibility of the Psychiatrist to His Society, in Psychiatric ETHIcs (S. Bloch \& P. Chodoff eds. 1981). During this time, German physicians may have been the most skilled in the "Western world from a purely technical point of view . . . [but] they had ceased to be members of an ethical profession . . . they dispens[ed] life and death with equal skill." Derr, supra note 34. Judge Bazelon also notes that the "medical label 'sick' has been used by Soviet psychiatrists to serve the political purposes of the state." Bazelon, supra note 53 , at 78 .

84. Even legitimate duties to third-parties may have an unjustifiable impact on the doctor-patient relationship. One critic notes that:

[I]f physicians include benefits to others in their calculations, patients have to be told that their physicians have conflicting agendas. The Hippocratic Oath would have to be removed from the waiting room wall and replaced with a sign that says, "Warning all ye who enter here. The physician will at times abandon your interests in order to benefit others . . . ."

Veatch, Commentary to the HMO Physician's Duty to Cut Costs, 15 Hastings Center Rep. 13, 14 (1985).

85. See supra note 16 (many states require that insane condemned be placed in state mental hospitals).

86. For example, the right of free speech explicitly encompasses the ability of citizens to express, without penalty, their displeasure with state action. U.S. Const. Amend. I. See, e.g., Cohen v. California, 403 U.S. 15 (1971) (speech clause protects right to express displeasure with draft).

87. The Supreme Court's interpretation of the free exercise clause of the First Amendment supports this view. The Amish may exempt themselves from compulsory education laws. Wisconsin v. Yoder, 406 U.S. 205 (1972). The Jehovah's Witnesses may refuse to salute the flag during the Pledge of Allegiance. West Virginia State Bd. of Educ. v. Barnette, 319 U.S. 624 (1943).

The most apt analogy is that of the conscientious objector during the era of the Selective Service. Persons opposed to war in any form on religious grounds were exempted by statute from military service. In Welsh v. United States, 398 U.S. 333 (1970), Justice Black's plurality opinion held that an exemption on moral, ethical, or religious principle was sufficient to fall within the statute.

This Note does not propose that the physician's ethical principles should be cognizable as a religion within the meaning of the First Amendment. It does argue, however, that a deeply held, sincere belief in these ethical principles has substantial weight and must be carefully considered by the state.

88. Chodoff, supra note 83, at 308 (commenting on responsibilities of citizenship for physicians). 


\section{B. Protecting the Integrity of the Medical Profession}

The state has a countervailing and equally compelling interest in protecting the ethical integrity of physicians. ${ }^{89}$ These ethical principles usually center around the physician's duty to her patient. ${ }^{80}$ For example, medical ethics are a factor to be weighed against the right of the patient to refuse treatment on religious grounds. ${ }^{91}$ Courts have recognized that professional codes of ethics may provide an exception to the employment termination-at-will doctrine. ${ }^{92}$ Also, the state punishes those who attempt to subvert medical ethics. ${ }^{93}$ The well-established state interest in protecting the ethical integrity of physicians counters and undermines its interest in the use of the medical profession in the treatment of the insane condemned.

\section{G. State Interest in Protecting the Public Health}

The state's interest in protecting the public health requires it to ensure both the availability of competent, ethical physicians, and a population with sufficient trust in physicians to avail themselves of medical care. One manifestation of this intent is state authorization of the licensing of physi-

89. See, e.g., Superintendent of Belchertown State School v. Saikewicz, 373 Mass. 728, 743, 370 N.E.2d 417, 426 (1977) (state interest in ensuring ethical integrity of medical profession); In re Conroy, 98 N.J. 321, 351-52, 486 A.2d 1209, 1224 (1985) (state interest in "safeguarding the integrity of the medical profession").

90. See In re Conroy, 98 N.J. at 351-52, 486 A.2d at 1224; see also United States v. George, 239 F. Supp. 752, 754 (D. Conn. 1965) (in determining course of treatment, doctor's conscience and professional oath must be respected); Superintendent of Belchertown State School, 373 Mass. at 741, 370 N.E.2d at 426 (recognizing that prevailing medical ethical standards in determining right to refuse treatment did not mandate treatment for the terminally ill); John F. Kennedy Memorial Hosp. v. Heston, 58 N.J. 576, 583, 279 A.2d 670, 673 (1971) (when interests of hospital physicians were "pitted against the belief of the patient," court resolved problem by permitting hospital physicians to pursue treatment "according to their professional standards"). The ethics asserted in competency to be executed proceedings directly affect the doctor-patient relationship.

91. See, e.g., United States v. George, 239 F. Supp. at 754 (patient cannot dictate course of treatment on religious grounds which would ignore mandates of doctor's professional oath).

92. Pierce v. Ortho Pharmaceutical Corp., 84 N.J. 58, 71, 417 A.2d 505, 512 (1980). The Court stated: "[e]mployees who are professionals owe a special duty to abide not only by . . . law, but also by the recognized codes of ethics of their professions. That duty may oblige them to decline to perform acts required by their employers." Id. In Pierce, a physician invoked the Hippocratic Oath as grounds for refusal to continue her research on a drug containing saccharin. The Court noted that while use of saccharin was in controversy, her complaint did not allege, nor were facts adduced, that would prove that the pharmaceutical company would actually test the drug on humans. Therefore, the invocation of the Oath to "do no harm" was not implicated. Id. at 513-14.

Under the causation model this Note proposes, supra notes 61-62 and accompanying text, the psychiatrist who treats the insane condemned assists in the execution of her patient, an indisputable "harm." Hence, were a psychiatrist to refuse to treat an insane prisoner under these circumstances, she might successfully assert her ethical refusal as a defense to any employment sanction imposed by the state.

93. Thus, one court has held that as a matter of public policy, the Hippocratic Oath provides legal protection for communications between doctor and patient, and an insurance company which interferes with this relationship can be held to respond in damages. See Hammonds v. Aetna Casualty \& Surety Co., 243 F. Supp. at $797,801$. 
cians, reflecting state interests in the quality of care and medical services provided to patients. ${ }^{94}$ To further this interest, the state must protect both the ethical integrity of the medical profession, and the public's perception of the role physicians play in society. Thus, substantial interests militate against the appearance of medical participation in the death penalty. The spectre of the physician donning the executioner's hood inspires little confidence among people who receive medical treatment from the same physician. ${ }^{95}$ Also, sociological studies show that institutional actors internalize the values of their workplace. ${ }^{96}$ For physicians who participate in the death penalty process, the result may be a diminution of respect for the sanctity of human life, an attitude which conflicts with the state interest in the public health.

\section{Possible Resolutions to the Ethical Dilemma}

By drafting statutes that codify a common law prohibition against executing the insane, and by implementing these statutes with a process that uses psychiatrists, the state has posed an insoluble ethical dilemma for psychiatrists. Treating a condemned inmate pursuant to these statutes pits the role of healer, which is the essence of being a physician, squarely against the injunctions to do no harm and to take no life.

Although the state has an interest in executing the condemned, state interests can be asserted both for and against the use of physicians in treatment. In this case, particularly given the strength and nature of the interests involved, it is not legitimate for the state to enact statutes that alternatively invite or, in the case of state employees, coerce the medical profession to breach its ethics.

The state might have resolved the problem by concluding that the exemption for the insane from execution is a policy that has lost relevance in the modern world, or is a form of "inverted humanitarianism," cute all of the condemned without view to competency. ${ }^{98}$ For those indi-

94. See, e.g., Conn. Gen. STat. § 20-9, -10 (1985) (listing requirements for licensure).

95. Historical perception by the public of the executioner is "hard, uncaring, almost monster-like, a professional killer whose work is made legal." Finks, supra note 80 , at 383 . The Human Rights Advocacy Committee at the Florida State Mental Hospital at Chattahoochee stated their concern: "[T]reatment of such prisoners [incompetent condemned pursuant to Florida statute] would erode hospital morale, since some patients would find it difficult to trust staff who someday might recommend another patient's execution." 20 Psychiatric News, supra note 31, at 14-15.

96. See In the Service of the State: The Psychiatrist as Double Agent, 8 Hastings Center Rep. 1, 3-4 (Spec. Supp. Apr. 1978); see also, Bazelon, supra note 53, at 79.

97. "Is it not an inverted humanitarianism that deplores as barbarous the capital punishment of those who have become insane after trial and conviction, but accepts the capital punishment of sane men." Phyle v. Duffy, 34 Cal. 2d 144, 159, 208 P.2d 668, 676-77 (1949) (Traynor, J., concurring).

98. Medical ethics would not be violated if the state chose to execute all condemned inmates without regard to sanity, because the state would execute whether the physician treated or not, and her intervention would in no way cause the death. This solution is consistent with the argument 
viduals who believe that the execution of the insane is more barbarous or less meaningful than a normal execution, such a solution would have been unacceptable. After Ford, it is also clearly unconstitutional. ${ }^{89}$

Alternatively, the state could accord the status of a conscientious objector to state psychiatrists troubled by the prospect of treating these individuals. A legislative exemption would insulate the physician from the retaliatory and coercive powers of the state. ${ }^{100}$ One obvious objection is that the state has not rescued the physician from the dilemma that the state has created; rather, the state has simply permitted the psychiatrist to choose without penalty one prong of the conflict. This solution rests on the notion that statutes which cannot be implemented without causing a profession to violate its ethics are permissible if the state does not penalize either of the conflict-laden choices it permits. The propriety of setting up the conflict in the first place remains problematic. And the state should be aware that by relying on volunteer physicians to render treatment, it is relying on a group of physicians who practice near the border of what the profession has defined as ethical conduct. ${ }^{101}$

The state could achieve its interest in execution by using other professions to fulfill the statutory obligation. Nurses, psychologists and social workers on the staff of state hospitals all are experienced in the care and treatment of the mentally ill. However, illnesses that rise to the level of incompetence are usually treated with psychotropic drugs, ${ }^{102}$ which require doctors for administration. Further, it is possible that the ethics of psychologists, social workers, and nurses would also prohibit treatment under these circumstances. ${ }^{103}$

Finally, subsequent to a finding of incompetency to be executed, the state may choose to involve the medical profession in treatment pursuant to existing statutes. Should the state elect this course, this Note proposes that it should not do so at the expense of the ethical integrity of the medi-

advanced in this Note, which takes no position with respect to the propriety of the death penalty.

99. Ford v. Wainwright, 106 S. Ct. 2595 (1986).

100. Gary Alvord, the condemned inmate currently undergoing treatment pursuant to the Florida competency statute, has been treated by volunteer staff because of serious questions about the ethics of treating him that were raised by the hospital staff. See Krasnow, supra note 25, at A-1, col. 6 .

101. In this regard, the experience of the state with testimony on future dangerousness is instructive. The APA has taken the position that psychiatric testimony in capital proceedings on the subject of future dangerousness is improper. See Barefoot Amicus Brief, supra note 12 (criticizing role of psychiatrists in these proceedings). The state continues to call for psychiatric testimony, and psychiatrists step forward to testify. The result, however, is that a small number of psychiatrists who are willing to testify over the objections of the profession dominate and distort the process. In twenty cases in which mental health professionals testified on future dangerousness, a total of 29 witnesses testified. Eight testified once, and two others testified in 12 and 9 cases respectively. Dix, Participation by Mental Health Professionals in Capital Murder Sentencing, 1 INT'L J.L. \& Psychiatry 283, 291 (1978).

102. See supra note 26 and accompanying text.

103. $C f$. case cited supra note 35 (ethics of nursing profession). 
cal profession. Rather, because treatment by physicians under these circumstances results in a serious breach of professional ethics, and because the state has conflicting interests at stake, the state-should defer to medical ethics. The only way to achieve this accommodation is to specify in advance that subsequent to a finding of incompetence to be executed, and prior to treatment by a physican, the sentence of the insane condemned will be commuted to life imprisonment. ${ }^{104}$ Because treatment would no longer be equated with doing harm to the patient and taking life, the physician could heal the inmate free of ethical betrayal.

\section{Conclusion}

The states have enacted and implemented competency to be executed statutes that pose an irreconcilable ethical conflict for the medical profession. Based on an analysis of the relevant medical ethics and state interests, this Note contends that the state must accommodate the ethical integrity of the medical profession. ${ }^{105}$ This proposal is not revolutionary. The state has traditionally respected and upheld the ethical integrity of various professions. It must now do so in the context of medical treatment of the insane condemned, because to do otherwise results in the anathema of making "one learned profession the very agent of an attack upon the ethical foundations of another."106

104. This model accords with the proposal by staff members currently struggling with the ethical implications of treating the incompetent condemned in Florida. See supra note 73 and accompanying text. It further accords with the British experience. Although English common law provided that a condemned prisoner whose sanity was restored could be executed, no persons have actually been executed since the early 1840's. Radelet \& Barnard, supra note 5, at 38 . England currently has no death penalty.

105. See, e.g., Nix v. Whiteside, 106 S. Ct. 988 (1986) (against charge of incompetent counsel, Court recognized defense based on legal ethics and found professional ethic supplants duty of zealous advocacy). Although the ethics of the legal profession are often codified in statutes and carry the weight of law, in this case the Court also explicitly alluded to the weight given canons and codes of professional ethics. Id. at 994-96.

106. Derr, supra note 34 , at 30 . (referring to legal judgment that would permit physicians to deny patients food and fluids). 